\title{
Sketch of Discourse and Power in Don DeLillo's White Noise
}

\author{
Ruzbeh Babaee \\ Faculty of Modern Languages and Communication, University Putra Malaysia \\ Wan Roselezam Bt Wan Yahya \\ Faculty of Modern Languages and Communication, University Putra Malaysia \\ Siamak Babaee \\ Department of Foreign Languages, University of Kashan-Iran
}

Received: 17-10- 2013

doi:10.7575/aiac.ijclts.v.2n.1p.30
Accepted: 25-12- 2013

Published: 10-01- 2014

\begin{abstract}
In White Noise (1985), Don DeLillo shows the web of systems predominating late twentieth century society. DeLillo illustrates the organizations of supermarket, media, and even drug as new discourses of power in postmodern condition in which, according to Michele Foucault, power is diffuse, and power conflicts can happen at many different sites and levels. This study is an exegesis of Foucault's central concept for understanding representations, and the intersections of discourse, power, and the subject in Don DeLillo's White Noise in which power disseminates through different social and cultural discourses.
\end{abstract}

Keywords: Discourse, Power, Knowledge, Truth, Metanarrative

\section{Introduction}

Discourse is designed for investigating challenges over meaning and other power conflicts, since Michele Foucault assumed that any society would be infused with different kinds of discourses. As Foucault states, "Each society has its regime of truth. Its 'general politics' of truth - that is, the types of discourse it accepts and makes function as true, the mechanism and instances that enable one to distinguish true and false statements" (Essential 131). Hence, power can emerge at a variety of sites and levels. ${ }^{1}$ Foucault observed discourse as an area, maybe like a magnetic field, encompassing all the different lines of force grouped around a set of magnetic poles. ${ }^{2}$ Discourse also has another major function; discourse assumes that notions make social space, and thus notions can play a critical role in historical alteration. As Lois Tyson argues, discourse is a social language made via especial cultural situations at an especial time and place, and it represents an especial approach of comprehending human experiences. Discourse concerns especial patterns of language telling us something about the people who speak the language, the culture that people belong to, the social networks that the people are part of, and even the most basic beliefs that people hold.

Foucault's critique is useful for exposing the power of systems of thought to regulate and control society, those that make true discursive formations which might have very little actual validity. Such a concern is of relevance for scholars in quest of understanding the concept of the power of discourse. Due to the scope of this paper and space restrictions, what follows is not a comprehensive critical engagement with Foucault's extensive oeuvre, but is rather an exegesis of his central concepts for understanding representations, and the intersections of discourse, power, and truth in Don DeLillo's White Noise that, according to Engles and Duvall, in Approaches to Teaching DeLillo's White Noise, is one of the most discussed pieces of fiction due to its accessibility and brilliant treatment of various issues in contemporary American culture; Engles and Duvall claim that DeLillo's novel concerns contemporary American society and depicts issues such as toxicity, mass media, terrorism, consumerism, conspiracy and paranoia. This study investigates how DeLillo shows manipulation of human beings through social and cultural discourses. It is essential to understand the intersections of Foucault's concept of discourse and White Noise's presentation of discourse; the two are of course not equal, but the diminished center of authority in each suggests certain affinities.

\section{Manifestation of Discourse}

According to Foucault in The Archaeology of Knowledge, discourse has four major functions: 1) discourse creates the universe, 2) discourse produces truth and knowledge, 3) discourse reveals something about the individuals speaking it, 4) discourse produces power. All these four functions are interrelated as the emergence of one leads to the other.

DeLillo in White Noise illustrates a society constituted accordance with these four ways of discourse. Based on the first function, Foucault argues that by forming our perception of the universe, pulling together the chain of association producing a meaningful perception, and then organizing the approach, we behave toward objects in the universe and toward other individuals, discourse produces the world of our daily life. Discourses have a crucial function in the social construction of reality. In White Noise, for instance, discourse is created by the interaction between media, technology, advertisement, and personal experience and then it creates a world for the protagonist- Jack Glandney- who says, "[...] 
I read the TV listings, I read the ads in Ufologist Today. I want to immerse myself in American magic and dread" (White Noise, 22). For DeLillo, discourse is made by humans' interaction with their environment. It is discourse that shapes Jack's perception of the world.

Based on the second function, discourse makes not only the universe that we live in, but also it forms the knowledge and truth surrounded us. For Foucault, discourse produces truth or truth-effects. Particulars discourses in particular contexts have the power to persuade individuals to accept statements as truth. In White Noise media have the power to produce truth. Delillo depicts it in a conversation between Jack and his son Heinrich as they are driving to school in the rain. Heinrich told his dad that, in spite of what looks like rain on the windshield, the radio said it wasn't going to rain until that night.

His dad is frustrated. "Just because it's on the radio doesn't mean we have to suspend belief in the evidence of our senses."

"Our senses? Our senses are wrong a lot more often that they're right. This has been proved in the laboratory. Don't you know about all those theorems that say nothing is what it seems?" (White Noise, 25)

For DeLillo, media are able to produce discourses of truth that are accepted blindly by people who put their beliefs in them.

Based on the third function, discourse produces knowledge about the meaning of the language as well as the individual who speaks the discourse. Via examining the discourse people use, things can be said about their ethnicity, gender, social class, and even more especially the speaker's relationships with the other people. Computerized or technological discourses, for example, in White Noise, give the authority to computer and media to speak thereby placing them in a position of power over common people like Jack. As a SIMUVAC officer tells Jack,

I didn't say it. The computer did. The whole system says it. It's what we call a massive data-base tally. Gladney, J.A.K. I punch in the name, the substance, the exposure time and then I tap into your computer history. Your genetics, your personals, your medicals, your psychological, your police- and- hospitals. It comes back pulsing stars... It just means you are the sum total of your data. No man escapes that (White Noise, 165).

Through SIMUVAC, DeLillo looks at a mode of discourse that not everyone has a right to use, or that needs especial locations to obtain power. ${ }^{3}$

Based on the fourth function, discourse involves in socially made systems of power. Especial types of discourse make particular types of people able to speak the truth, or at least to be believed when speaking on particular subjects. Discourse also gives these people degrees of cultural, social, and even political power. DeLillo shows this kind of discourse through illustrating Jack as the chair of the Hitler Studies department at College-on-the-Hill. This position gives Jack the power to speak and even hold a conference on Hitler Studies, while he cannot speak even one word German. He says; "Hitler gave me something to grow into and develop towards, tentative as I have sometimes been in the effort" (White Noise, 19).

For Foucault, discourse generates the meanings of objects and practices; a notion that leads to the argument that nothing can exist outside discourse. Such a position is not denying the existence of the physical world, but is rather arguing that meaning is never intrinsic, as it is people who ascribe meaning to things. This point leads to the argument, namely that, media are infused with discourse defining the meaning of media representations. In postmodern condition where in a sense both Foucault and DeLillo belong to; media try to determine the truth. In White Noise, Murray-a visiting lecturerargues that "TV offers incredible amounts of psychic data. It opens ancient memories of world birth, it welcomes us into the grid, the network of little buzzing dots that make up the picture pattern" (White Noise, 61). Thus, media are full of the discourses that surround and define the events being represented, and they are the symbolic results of a discursive practice. As such, media can make only a provisional claim to truth as truth can never be achieved in its pure via the confined symbolic constraints of discourse as well as the confined physical constraints of the medium.

\section{The Aura of Postmodern Discourse}

We know of no other fiction that concerns postmodernism better than White Noise that is "another postmodern sunset, rich in romantic imaginary" (White Noise, 260). Don DeLillo in White Noise illustrates the web of discourses that predominate in postmodern condition. DeLillo's depiction of the authority of supermarkets, media, science, and institutions such as university and police are all components of what Foucault concerns as the discourse of power. Thus, in this system of power, metannartives such as ideology, Marxism, religion are replaced by discourse which determines the truth for people. As Heinrich says, "The real issue is the kind of radiation that surrounds us every day. Your radio, your TV, your microwave oven, your power lines just outside the door, your radar speed- trap on the highway. For years they told us these low doses weren't dangerous" (White Noise, 202). In the society of White Noise, the truth is not generated through metanarratives or what Lyotard calls "Grand of narratives" that are untold stories tending to unify and totalize the universe, and to justify a culture power structure. Jean-Francis Lyotard rejects the "grant of narrative" of progress and perfectibility in favor of uncertainties or provisional conditions. DeLillo also portrays the failure of the totality of metanarratives in postmodernism in which one day media is in authority, the other day consumerism and shopping centers, and once science and Dylar- a fictional drug-, while human leaves symbolically one to another, as Jack says: "We moved from store to store, rejecting not only items in certain departments, not only entire departments 
but whole stores, mammoth corporations that did not strike our fancy for one reason or another" (White Noise, 99). Thus, DeLillo is in line with Foucault who observes that power is not an absolute concept. Foucault states that

Power comes from below; that is, there is no binary and all-encompassing opposition between rulers and ruled at the root of power relations, and serving as a general matrix - no such duality extending from the top down and reacting on more and more limited groups to the very depths of the social body. (Foucault Sexuality17)

He sees power as being scattered through the networks of relationship making up society. This is not to deny the idea that power struggle can be unequal but to propose that it is not practiced in a single way. For Foucault, a significant ingredient of power is freedom since power is only able to create an effect if the object of power has the capability of resistance.

Similarly, Lyotard notes that we live in an era when metanarratives can simply no longer account for, and apply to, all aspects of human experiences. He states, "the grand narrative has lost its credibility, regardless of what mode of unification it uses, regardless of whether it is a speculative narrative or a narrative of emancipation" (The Postmodern Condition37). Here, we face the simple fact that the world does not make sense in any simple way, according to any single discourse. DeLillo, Foucault, and Lyotard would agree that the age of the metanarratives has ended; DeLillo sees more of lack of security, when Jack says, "No one's knowledge is less secure than your own" (White Noise, 140). DeLillo is obsessed with discourses that are loops that people get caught up in, they are media, science, advertisement or personal discourses that people create and cling to in times of trouble, because if something is part of a discourse, it has a reason. DeLillo recognizes that there is something very human in the belief that there must be an underlying logic to human events, that there must be a reason for everything that occurs, and that it must fit into some discourses. As Murray says to Jack "Kill to live" (White Noise, 335). Killing is the reason for living in Murray's eyes.

In White Noise, Jack is in quest of finding relief for his existential angst in a whole series of discourses such as consumerism, science, and media. He talks of his angst as: "Facts threaten our happiness and security. The deeper we delve into the nature of things, the looser our structure may seem to become" (White Noise, 97). He is in the position of appreciating the ironies of contemporary existence while simultaneously being subject to them.

Consumerism is another discourse of the twentieth century. There is a belief, produced through media advertising, that one can shop his/her way out of any personal trauma. When shopping, people may define an identity, an idea of who they are. As Jack says about shopping:

It seems to me that Babette and I, in the mass and variety of our purchases, in the sheer plenitude those crowded bags suggested, the weight and size and number, the familiar package designs and vivid lettering, the giant sizes, the family bargain packs with Day-Glo sale stickers, in the sense of replenishment we felt the sense of well-being, the security and contentment these products brought to some snug home in our souls- it seems we had achieved a fullness of being that is not known to people who need less, expect less, who plan their lives around lonely walks in the evening. (White Noise, 24).

While shopping suggests a sort of relief for Jack, and a feeling of control over his life, Jack soon understands that his economic and social conditions are still of little significance in the grand scheme of things:

I'm not just a college professor. I'm the head of a department. I don't see myself fleeing an airborne toxic event. That's for people who live in mobile homes out in the scrubby parts of the country, where the fish hatcheries are (White Noise, 136-7).

The accidental toxic clouds, the natural disaster, the arbitrary act of violence, are the disturbing angst. The discourse of consumerism fails when it matters, in significant times of life and death. Jack is not able to buy his way out of his exposure to the toxic cloud. In dealing with his exposure, Jack must leave himself to another discourse, that of science.

Dylar is the chemical drug, which Jack's wife, Babette, has secretly been taking to counteract her fear of death. Facing the very real possibility of imminent death, Jack becomes obsessed with the drug, even though Babette said that it didn't work, that she still dreaded death. Jack is fascinated by the idea that a little white pill could contain the end to his fear. As he says,

Dylar is almost as ingenious as the microorganism that ate the billowing cloud. Who would have believed in this existence of a little white pill that works as a pressure pump in the human body to provide medication safely and effectively, and self-destructs as well? I am struck by the beauty of this (White Noise, 219).

Jack is reaching for the code of the system, but he is denied access to the discourse of science; Jack believes that there must be a solution to his problem that science and technology can provide, but he can't find the pill.

Finally, Jack appeals to a kind of Hitlerian discourse that is will to power. He decides that he will attempt to overcome death by causing the death of another. Throughout the novel, Jack had appealed to his professional life, to Hitler studies, to overcome his fear of death, "Some people are larger than life, Hitler is larger than death" (White Noise, 330). The idea behind this is that a tyranny so large, a horror so obscure, could overpower something as small as any individual's fear of death. However, after Jack actually does attempt to enact his will to power, and shoots Mr. Gray- Dylar Owner-, he finds: 
What else do we find? Certainly there is awe, it is all awe, it transcends previous categories of awe, but we don't know whether we are watching in wonder or dread, we don't know what we are watching or what it means, we don't know whether it is permanent, a level of experience to which we will gradually adjust, into which our uncertainty will eventually be absorbed, or just some atmospheric weirdness, soon to pass. (White Noise, 373)

Yet Jack must face death with no psychic relief. In White Noise, we clearly see that both discourse and Jack are failed. Jack, in his appeals to various systems, finds that none of them are genuine. In White Noise, the effect of all the discourses being autonomous is disorienting, discomforting, and disastrous. As Foucault argues, when all the discourses are equal, when all the narratives bear the same weight, and none has recourse to any kind of metaphysical reality; individual subjects are left to fend for themselves amid the frightening, dangerous babble of the narratives.

\title{
4. Conclusion
}

It is not easy to come to a conclusion where both Foucault and DeLillo are considered. Indeed, Alan Sheridan commences his last segment of Michel Foucault, The Will to Truth that is entitled "Conclusion" with the words, "This is no time for conclusions" (165). Both Foucault and DeLillo suggest no immediate solutions to the issue such as power, knowledge, and truth in postmodern condition; they just represent the ways power disseminates and control people's everyday life. Foucault represents discourse in an era where truth can change as a consequence of the very discourse using it as a premise. DeLillo, also, represents a bleak analysis of how we are brought to see a form of reality which considerably narrows our view of what is possible. DeLillo attempts to identify that how, in our own time, our perception of reality is changing when it falls into different discourses.

\section{References}

DeLillo, D. (2011). White Noise. Pan Macmillan

Engles T., and John N., Duvall, ed. (2006). Preface. Approaches to Teaching DeLillo's White Noise. New York, NY: Modern Language Association of America, 1-5.

Foucault, M. (1994). Essential Works of Foucault 1954-1984. Ed. James D. Faubion. London:Penguin

--- (1980).Two Lectures, Power/Knowledge: Selected Interviews \& Other Writings, 1972- 1977, ed. Colin Gordon, New York: Pantheon Books

--- (1972).The Archaeology of Knowledge (A. M. S. Smith, Trans.). New York: Pantheon Books

Lyotard, J. F. (1984). The Postmodern Condition: A Report on Knowledge. (Geoff Bennington and Brian Massumi Trans.). Minneapolis, MN: University of Minnesota Press

Sheridan, A. (1980). Michel Foucault, The Will to Truth. London

Tyson, L. (1999). Critical Theory Today: A User-Friendly Guide. New York and London: Garland Publishing

\author{
Notes \\ ${ }^{1}$. For more on this, see Foucault's Power/Knowledge \\ 2. Foucault, The Archaeology of Knowledge \\ 3 . ibid
}

